ISSN 2738-9898 (Print) ISSN 2738-9901 (Online)

\title{
Analysis of Climate Change Trend in the Lower Kaski District of Nepal
}

\author{
Keshav Basnet ${ }^{1}$, Anup Shrestha ${ }^{2}$, Prakash Chandra Joshi ${ }^{1}$, and Nisha Pokharel ${ }^{1}$ \\ ${ }^{1}$ Department of Civil and Geomatics Engineering, Pashchimanchal Campus, Institute of Engineering, Tribhuvan University, \\ Pokhara, Nepal \\ ${ }^{2}$ Department of Civil Engineering, Pokhara Engineering College, Pokhara University, Pokhara, Nepal
}

Corresponding E-mail: basnet.keshav@gmail.com

Received on: $18^{\text {th }}$ April., 2020

Accepted for publication: $27^{\text {th }}$ Oct., 2020

\begin{abstract}
Climate change is considered as the most critical global challenge of the century. Unusual precipitation pattern and outflanking of hydraulic structures frequently reported these days in the Kaski district of Nepal. This research aimed to analyze the trend of climate change in the lower Kaski using annual and seasonal weather data (2001-2017) of five meteorological stations out of which three on the upper tropical region, one on the sub-tropical region and the other one on the temperate region. Individual trend analysis was performed for rainfall and temperature patterns using Mann-Kendell test. Trend analysis for seasonal average precipitation shows an increasing trend for winter and pre-monsoon seasons and a decreasing trend for monsoon and post-monsoon seasons. In contrast, overall annual precipitation shows a decreasing trend. An increasing trend was found for maximum seasonal temperature for all seasons except pre-monsoon season. The seasonal minimum temperature shows a growing trend and overall annual trends for both the maximum and minimum temperatures were also increasing. All of these trends are the evidence of climatic changes that are happening over time. Additionally, a comparative study was conducted between a meteorological station and a locally established manual station. The differences in the numeric values of cumulative rainfall with comparable precipitation readings suggest the need to take into account local station data for design, construction, and planning of hydraulic structures.
\end{abstract}

Keywords: Global warming, Local rain gauge station, Mann Kendall test, Rainfall trend, Temperature trend.

\section{Introduction:}

Climate is the statistics of weather over long periods of time [1]. It is measured by assessing the patterns of variations in the temperature, humidity, atmospheric pressure, wind, precipitation, atmospheric particle counts and other meteorological variables in a given region over long periods. Climate Change typically is defined as the change in the state of the climate that can be identified by changes in the mean or the variability of its properties that persists for an extended period of time, typically decades or longer [1]. Climate change is one of the most critical global challenges of the century. The warming trend in Nepal after 1997 has ranged from 0.06 to $0.12{ }^{\circ} \mathrm{C}$ per year in most of the middle mountains and Himalayan regions [2].

The linear warming throughout 1880-2012 has been $0.85{ }^{\circ} \mathrm{C}$ with $1983-2012$, likely the warmest 30 years period of the last 1400 years in the 
Northern Hemisphere [1]. The warming trend in Nepal after 1997 has ranged from $0.06{ }^{\circ} \mathrm{C}$ to 0.12 ${ }^{\circ} \mathrm{C}$ per year in most of the middle mountains and Himalayan regions; this trend has been less than $0.03{ }^{\circ} \mathrm{C}$ per year in the Siwalik and Terai regions [2]. Predictions are constantly being made to understand what will happen based on observed climate shifts over the past decades and projected greenhouse gas emissions. Changing precipitation and temperature analysis trends are useful in engineering, environmental, forestry, and soil conservation studies. This trend analysis is necessary for proper engineering designs of hydrologic structures like dams, bridges, irrigation canals, sewerage, etc. Addisu et al. [3] conducted a time series trend analysis of rainfall and temperature in the Ethiopia's lake Tana Subbasin. Similarly, Shrestha [4] studied the variation of summer monsoon rainfall over Nepal and its relation to the southern oscillation index.

Nepal has amazingly diverse geological features and climatic conditions throughout the country. The hydrology of Nepal is mainly fed by the South Asian Monsoon System (SAM). Still, the relationship between the timing, volume of monsoon rainfall, and the mountain landscape are poorly understood [5]. The altitude variation over a short distance limits our ability to explain the precipitation pattern in Nepal. The data set required to explain the processes is also limited. With few Monitoring stations (just 280 across the entire country), the hydro-meteorological data has been collected only since the late 1960s [5]. The observed climate trend analysis of Nepal is available from 1971 to 2014 [6]. However, there is no study on climate change trend primarily focused on the Kaski district comparing the trend of various climatic zones.

The study area of this research is based on the Kaski district of Gandaki Province, Nepal (Fig. 1). It is located at latitude $28^{\circ} 18^{\prime} 19.08^{\prime \prime}$ North and longitude $84^{\circ} 04^{\prime} 37.20^{\prime \prime}$ East. The altitude of the Kaski district, with Pokhara as headquarter, ranges from lower 450 masl to upper 8091 masl in the Himalaya range. It has a Metropolitan City, 4 Rural Municipalities, and 3 Electoral Sectors. Basnet and Acharya [7] reported that Kaski is the area of high intensity of rainfall throughout the year in Nepal, and about $80 \%$ of rainfall occurs typically in four months; June, July, August, and September. With a focus on our study area, the unusual precipitation patterns are frequently being reported these days. Besides that, the overflow of the drain, outflanking of hydraulic structures such as bridges, dams, river training works, etc. are also observed recurrently. This incidence is not a mere coincidence, but the result of climatic changes happening over the course of time.

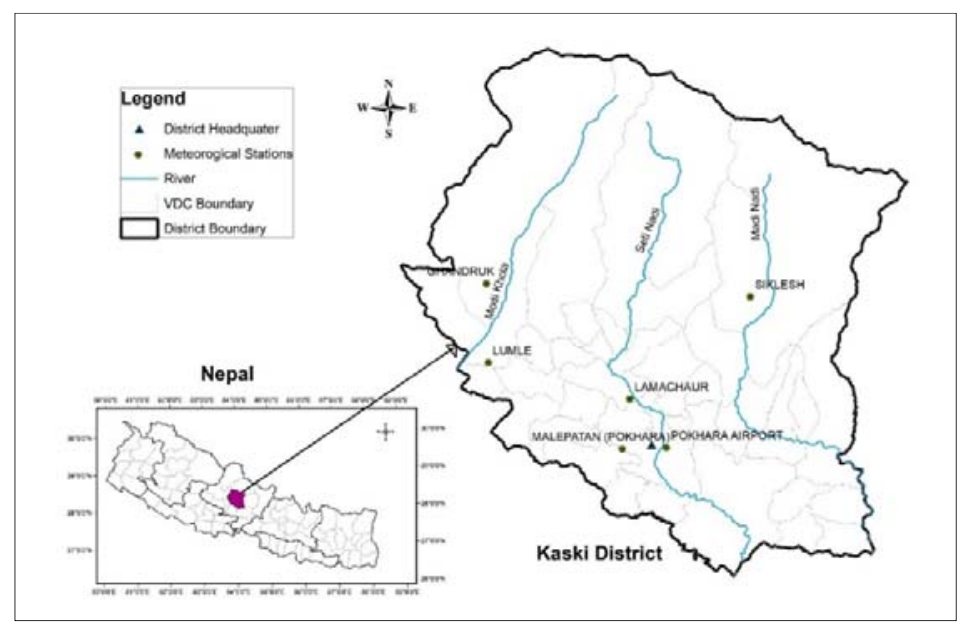

Figure 1: Location of the study area [Source: DDC, Kaski]

This study's main objective is to analyze the climate change trend in the Kaski district of Nepal. For that, the trend of rainfall and temperature in different climatic zones were analyzed, and also the need for local rain gauge stations in construction activities was assessed.
Based on this study, out of the seven climatic zones of Kaski district (see Table 1), only three climatic zones are taken for historical trend analysis. The results are based on Sen's slope and the established rain gauge is of manual type. 
This study's secondary objective is to compare the rainfall data relevant to the study area or proposed rainfall data collected from a manually established rain gauge device with the precipitation data of a DHM station. Researchers and hydraulic engineers in Nepal facing the problem of lack of site (e.g., while designing storm water drain, see [8]). For this purpose, a rain gauge was established manually to collect the local rainfall data [9].

Table 1: Geography of Kaski

\begin{tabular}{clcccc}
\hline S. No. & Climatic zone & $\begin{array}{c}\text { Elevation range } \\
(\mathbf{m})\end{array}$ & $\begin{array}{c}\text { Area per } \\
\mathbf{k m}^{2}\end{array}$ & $\begin{array}{c}\text { \%o of the } \\
\text { area }\end{array}$ & $\begin{array}{c}\text { Number of } \\
\text { stations }\end{array}$ \\
\hline \hline 1 & Upper tropical & 300 to 1,000 & 375.16 & 18.6 & 5 \\
2 & Sub-tropical & 1,000 to 2,000 & 592.98 & 29.4 & 9 \\
3 & Temperate & 2,000 to 3,000 & 334.82 & 16.6 & 1 \\
4 & Subalpine & 3,000 to 4,000 & 244.05 & 12.1 & 0 \\
5 & Alpine & 4,000 to 5,000 & 298.52 & 14.8 & 0 \\
6 & Nival & above 5,000 & 1492.58 & 7.4 & 0 \\
7 & Trans-Himalayan & 3,000 to 6,400 & 12.10 & 0.6 & 0 \\
\hline \hline
\end{tabular}

\section{Methodology:}

The research framework illustrated in Fig. 2 shows the methodology for obtaining the first and second objectives of this study. This study was based on the literature review, analysis of primary and secondary data. During the desk study stage, relevant documents and articles were identified, collected, and studied to obtain preliminary information about precipitation and temperature. Then, meteorological data were collected from the Department of Hydrology and Meteorology; and Meteorological Forecasting Division, Kaski. Out of fifteen meteorological stations of Kaski only five; three on the upper tropical region, one on the sub-tropical region and one on the temperate region were selected for data analysis as mentioned in Table 2. Since the meteorological data before 2001 was not available for all the stations, data only from 2001 to 2017 was used in this study though it is not sufficient for trend analysis. Secondary data were collected from different sources such as related publications, reports, literature, thesis, library, journals, magazines, internet etc. As mentioned in Table 2, the data from five different stations were studied for climatic change trend analysis.

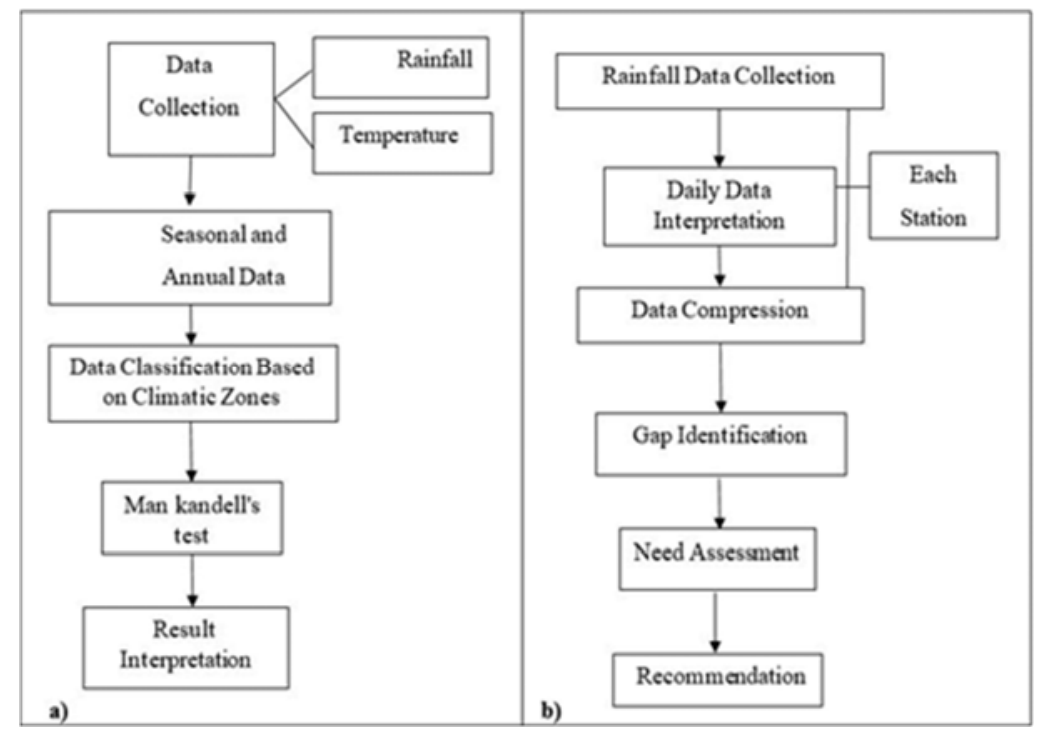

Figure 2: Research framework; a) for trend analysis and b) for need assessment. 
Trend analysis is the widespread practice of collecting information and identifying a pattern. The detection, estimation and prediction of trends and associated statistical and physical significance are important aspects of climate research $[10,11]$. Given a time series of (say) temperatures, the trend is the rate at which temperature changes over a time period which may be linear or non-linear. Simple linear regression is most commonly used to estimate the linear trend (slope) and statistical significance. The non-parametric (i.e. distribution free) MannKendall (M-K) test can also use to assess monotonic trend (linear or non-linear) significance. The non-parametric Mann-Kendall test is commonly employed to detect monotonic trends in series of environmental data, climate data or hydrological data [12]. The null hypothesis, $H_{0}$, is that the data come from a population with independent realizations and are identically distributed. In statistics, the Kendall rank correlation coefficient, commonly referred to as Kendall's tau coefficient (after the Greek letter $\tau$ ), is a statistic used to measure the ordinal association between two measured quantities. Being a non-parametric test, no necessity of normally distributed data and having low sensitivity to abrupt breaks due to inhomogeneous time series, this statistical method is preferred for climatologic trend time series analysis.

Table 2: Hydro-meteorological stations in the lower Kaski district. [Source: DHM, Nepal]

\begin{tabular}{cllccc}
\hline S. No. & Name of station & Station type & $\begin{array}{c}\text { Latitude } \\
\left({ }^{\circ} \mathbf{N}\right)\end{array}$ & $\begin{array}{c}\text { Longitude } \\
\left({ }^{\circ} \mathbf{E}\right)\end{array}$ & $\begin{array}{c}\text { Elevation } \\
(\mathbf{m})\end{array}$ \\
\hline \hline 1 & Pokhara Airport & Aeronautical & 28.13 & 84.00 & 827 \\
2 & Malepatan & Agrometeorology & 28.07 & 84.07 & 856 \\
3 & Lumle & Agrometeorology & 28.18 & 83.48 & 1740 \\
4 & Begnas & Climatology & 28.11 & 84.08 & 669 \\
5 & Panchase & Climatology & 28.13 & 83.47 & 2493 \\
\hline \hline
\end{tabular}

The Mann-Kendall S Statistic is computed [13] as follows:

$$
\begin{gathered}
S=\sum_{i=1}^{n-1} \sum_{j=i+1}^{n} \operatorname{sign}\left(T_{j}-T_{i}\right) \\
\left\{\begin{array}{c}
\operatorname{sign}\left(T_{j}-T_{i}\right)= \\
0, \text { if }\left(T_{j}-T_{i}>0\right) \\
1, \text { if }\left(T_{j}-T_{i}=0\right) \\
-1, \text { if }\left(T_{j}-T_{i}<0\right)
\end{array}\right.
\end{gathered}
$$

where, $j>i$ and $T_{\mathrm{j}} \& T_{\mathrm{i}}$ are the annual values in $j$ and $i$ years, respectively.

In equation (1), if $n<10,|S|$ is compared to the theoretical distribution of $S$ which is derived from a two tailed Mann and Kendall test. If the absolute value of $S$ equals or exceeds a specified value $S_{\alpha / 2}$, where $S_{\alpha / 2}$ is the smallest $S$ with probability $<\alpha$ $/ 2, H_{0}$ is rejected in favor of $H_{1}$ to appear in case of no trend. A positive value of $S$ indicates an upward trend and vice-versa [14]. For $n \geq 10, \mathrm{~S}$ is normally distributed with the mean and variance $\left(\sigma^{2}\right)$ as:

$$
\sigma^{2}=\frac{n(n-1)(2 n+5)-\sum T_{i}(i)(i-1)(2 i+5)}{18}
$$

In equation (3), $T_{\mathrm{i}}$ denotes the number of ties to extent $i$. If only the data series contains tied values, the summation term in the numerator is used.

The standard test statistic $Z_{\mathrm{s}}$ is used a measure of significance of trend, and is calculated as follows:

$$
Z_{s}=\left\{\begin{array}{l}
\frac{s-1}{\sigma} \text { for } S>0 \\
0 \text { for } S=0 \\
\frac{s+1}{\sigma} \text { for } S<0
\end{array}\right.
$$

The null hypothesis, $H_{\mathrm{o}}$ is checked using this test statistic. If $\left|Z_{\mathrm{s}}\right|>Z_{\alpha / 2}$, where $\alpha$ is the chosen significance level (e.g., $5 \%$ with $Z_{0.025}=1.96$ ) then the null hypothesis is invalid which implies that the trend is significant [13]. Similarly, on running the Mann-Kendall test another statistic is obtained; Kendall's tau. It is a measure of correlation that measures the strength of the 
relationship between the two variables, and is carried out on the ranks of the data. For each variable separately, the values are put in order and numbered, 1 for the lowest value, 2 for the next lowest and so on. Kendall's tau takes values of range $[-1,1]$. A positive correlation indicates that the ranks of both variables increase together and a negative correlation indicates that as the rank of one variable increases, the other decreases [15].
Autocorrelation or serial correlation is defined as the correlation of a variable with itself over successive time intervals, prior to testing for trends. It increases the chances of detecting significant trends even if they are absent and vice versa. Hence, it is essential to be considered in the time series analysis. Autocorrelation between the ranks of the data can be calculated as suggested by Hamed and Rao (1998) after removing the apparent trend [16]. The adjusted variance is given as:

$$
\begin{aligned}
& V A R[S]=\frac{1}{18}[N(N-1)(2 N+5)] \frac{N}{N S^{*}} \\
& \frac{N}{N S *}=1+\frac{2}{N(N-1)(N-2)} \sum_{i=1}^{p}(N-i)(N-I-1)(N-i-2) P_{S}(i)
\end{aligned}
$$

In equation (5), $N$ is the number of observations in the sample, $N S^{*}$ is the effective number of observations to account for autocorrelation in the data, $P_{\mathrm{s}}(i)$ is the autocorrelation between ranks of the observations for lag $i$, and $p$ is the maximum time lag under consideration [17].

Addinsoft's XLSTAT 2018 was used for performing the statistical Mann-Kendall test. For both, temperature and precipitation data he null hypothesis was tested at $95 \%$ confidence level. After that, linear trend lines were plotted to compare the results obtained from the MannKendall test.

\section{Result and Discussion:}

\subsection{Maximum and Minimum Precipitation:}

Precipitation analysis for three stations (Pokhara Airport, Malepatan and Lumle) of Kaski, performed from 2001 to 2008 is presented in Table 3, which shows that the annual precipitation is maximum in Lumle station and minimum in Malepatan station. Similarly, the analysis of precipitation for the period of 20092017 with two additional stations (Begnas station and Panchase station) of Kaski, given in Table 4, shows that the annual precipitation is maximum in Lumle station while the minimum is in Panchase station during the 2009-2017 period. The data from both the tables confirm that the Kaski district has the maximum rainfall in July and the minimum rainfall in December.

Table 3: Maximum and minimum precipitation (2001-2008).

\begin{tabular}{lccccc}
\hline $\begin{array}{c}\text { Name of } \\
\text { station }\end{array}$ & $\begin{array}{c}\text { Total } \\
\text { precipitation } \\
(\mathbf{m m})\end{array}$ & $\begin{array}{c}\text { Monthly } \\
\text { maximum } \\
\text { precipitation } \\
\text { (mm) }\end{array}$ & $\begin{array}{c}\text { Monthly } \\
\text { minimum } \\
\text { precipitation } \\
\text { (mm) }\end{array}$ & $\begin{array}{c}\text { Annual } \\
\text { maximum } \\
\text { precipitation } \\
\text { (mm) }\end{array}$ & $\begin{array}{c}\text { Annual } \\
\text { minimum } \\
\text { precipitation } \\
\text { (mm) }\end{array}$ \\
\hline \hline $\begin{array}{l}\text { Pokhara } \\
\text { Airport }\end{array}$ & 30994.0 & $7181.3(\mathrm{July})$ & $71.4(\mathrm{Dec})$ & $4512.5(2001)$ & $3262.7(2008)$ \\
Malepatan & 30310.8 & 7558.7 (July) & $80.8(\mathrm{Dec})$ & $4251.5(2007)$ & $2982.5(2006)$ \\
Lumle & 45348.8 & $11535.0(\mathrm{July})$ & $93.3(\mathrm{Dec})$ & $6310.2(2003)$ & $4294.7(2006)$ \\
\hline \hline
\end{tabular}


Table 4: Maximum and minimum precipitation (2009-2017).

\begin{tabular}{lccccc}
\hline $\begin{array}{c}\text { Name of } \\
\text { station }\end{array}$ & $\begin{array}{c}\text { Total } \\
\text { precipitation } \\
(\mathbf{m m})\end{array}$ & $\begin{array}{c}\text { Monthly } \\
\text { maximum } \\
\text { precipitation } \\
\mathbf{( m m )}\end{array}$ & $\begin{array}{c}\text { Monthly } \\
\text { minimum } \\
\text { precipitation } \\
\text { (mm) }\end{array}$ & $\begin{array}{c}\text { Annual } \\
\text { maximum } \\
\text { precipitation } \\
\text { (mm) }\end{array}$ & $\begin{array}{c}\text { Annual } \\
\text { minimum } \\
\text { precipitation } \\
\text { (mm) }\end{array}$ \\
\hline \hline $\begin{array}{l}\text { Pokhara } \\
\text { Airport }\end{array}$ & 32304.0 & $8418.2(\mathrm{July})$ & $43.3(\mathrm{Dec})$ & $3970.0(2014)$ & $3256.4(2016)$ \\
Malepatan & 33567.3 & $9084.5(\mathrm{July})$ & $197.3(\mathrm{Dec})$ & $4462.5(2017)$ & $3033.7(2009)$ \\
Begnas & 28648.0 & $7657.4(\mathrm{July})$ & $43.0(\mathrm{Dec})$ & $3600.9(2011)$ & $2424.6(2009)$ \\
Lumle & 46276.9 & $14330.0(\mathrm{July})$ & $67.0(\mathrm{Dec})$ & $5700.4(2010)$ & $4688.5(2015)$ \\
Panchase & 23164.0 & $6796.9(\mathrm{July})$ & $10.5(\mathrm{Dec})$ & $3875.0(2014)$ & $1782.9(2010)$ \\
\hline \hline
\end{tabular}

\subsection{Precipitation Trend:}

\subsubsection{Seasonal Precipitation Trend}

Table 5: Seasonal precipitation trend (2001-2008).

\begin{tabular}{|c|c|c|c|c|c|c|c|c|c|}
\hline $\begin{array}{c}\text { S. } \\
\text { No. }\end{array}$ & $\begin{array}{l}\text { Name of } \\
\text { Stations }\end{array}$ & $\tau$ & $\begin{array}{c}\text { p- } \\
\text { value }\end{array}$ & $\begin{array}{l}\text { Sen's } \\
\text { Slope }\end{array}$ & Trend & $\tau$ & $\begin{array}{c}\text { p- } \\
\text { value }\end{array}$ & $\begin{array}{l}\text { Sen's } \\
\text { Slope }\end{array}$ & Trend \\
\hline & & \multicolumn{4}{|c|}{ Winter } & \multicolumn{4}{|c|}{ Pre- Monsoon Season } \\
\hline 1 & $\begin{array}{l}\text { Pokhara } \\
\text { Airport }\end{array}$ & -0.14 & 0.71 & -1.59 & Decreasing & -0.07 & 0.90 & -1.59 & Decreasing \\
\hline 2 & Malepatan & -0.22 & 0.47 & -6.09 & Decreasing & -0.06 & 0.92 & -14.15 & Decreasing \\
\hline \multirow[t]{2}{*}{3} & Lumle & -0.06 & 0.92 & -1.70 & Decreasing & -0.61 & 0.03 & -13.89 & Decreasing \\
\hline & & \multicolumn{4}{|c|}{ Monsoon Season } & \multicolumn{4}{|c|}{ Post Monsoon Season } \\
\hline 1 & $\begin{array}{l}\text { Pokhara } \\
\text { Airport }\end{array}$ & -0.57 & 0.06 & -175.01 & Decreasing & 0.00 & 1.00 & 1.23 & Increasing \\
\hline 2 & Malepatan & -0.50 & 0.08 & -240.92 & Decreasing & -0.22 & 0.08 & -240.92 & Decreasing \\
\hline 3 & Lumle & -0.06 & 0.92 & -13.42 & Decreasing & -0.06 & 0.92 & -13.42 & Decreasing \\
\hline
\end{tabular}

Table 6: Seasonal precipitation trend (2009-2017).

\begin{tabular}{|c|c|c|c|c|c|c|c|c|c|}
\hline $\begin{array}{c}\text { S. } \\
\text { No. }\end{array}$ & $\begin{array}{l}\text { Name of } \\
\text { Station }\end{array}$ & $\tau$ & $\begin{array}{c}\text { p- } \\
\text { value }\end{array}$ & $\begin{array}{l}\text { Sen's } \\
\text { Slope }\end{array}$ & Trend & $\tau$ & $\begin{array}{c}\text { p- } \\
\text { value }\end{array}$ & $\begin{array}{l}\text { Sen's } \\
\text { Slope }\end{array}$ & Trend \\
\hline & & \multicolumn{4}{|c|}{ Winter } & \multicolumn{4}{|c|}{ Pre- Monsoon Season } \\
\hline 1 & $\begin{array}{l}\text { Pokhara } \\
\text { Airport }\end{array}$ & 0.06 & 0.92 & 0.94 & Increasing & 0.33 & 0.25 & 20.35 & Increasing \\
\hline 2 & Malepatan & 0.14 & 0.68 & 1.45 & Increasing & 0.17 & 0.60 & 9.94 & Increasing \\
\hline 3 & Begnas & 0.25 & 0.40 & 6.45 & Increasing & 0.11 & 0.75 & 7.90 & Increasing \\
\hline 4 & Lumle & 0.17 & 0.60 & 4.51 & Increasing & 0.39 & 0.18 & 12.70 & Increasing \\
\hline \multirow[t]{2}{*}{5} & Panchase & 0.22 & 0.47 & 4.36 & Increasing & 0.28 & 0.35 & 15.21 & Increasing \\
\hline & & \multicolumn{4}{|c|}{ Monsoon Season } & \multicolumn{4}{|c|}{ Post Monsoon Season } \\
\hline 1 & $\begin{array}{l}\text { Pokhara } \\
\text { Airport }\end{array}$ & 0.11 & 0.75 & 19.10 & Increasing & 0.11 & 0.75 & 4.63 & Increasing \\
\hline 2 & Malepatan & 0.28 & 0.35 & 83.96 & Increasing & 0.06 & 0.92 & 1.25 & Increasing \\
\hline 3 & Begnas & 0.01 & 1.00 & -6.80 & Decreasing & -0.11 & 0.75 & -3.35 & Decreasing \\
\hline 4 & Lumle & -0.39 & 0.18 & -102.88 & Decreasing & -0.06 & 0.92 & -1.80 & Decreasing \\
\hline 5 & Panchase & 0.39 & 0.18 & 142.38 & Increasing & -0.11 & 0.75 & -5.29 & Decreasing \\
\hline
\end{tabular}


As presented in Tables 5 and 6 , in the winter season, the average precipitation shows an increasing trend of $1.27 \mathrm{~mm}$ per season at the upper tropical range, $1.41 \mathrm{~mm}$ per season at the sub-tropical range and $3.36 \mathrm{~mm}$ per season at the temperaure range. In pre-monsoon season, the average precipitation shows an increasing trend of $0.01 \mathrm{~mm}$ per season at the upper tropical range, $15.21 \mathrm{~mm}$ per season at the temperature range and a decreasing trend of $0.60 \mathrm{~mm}$ per season in the sub-tropical range. In the monsoon season, the average precipitation shows an increasing trend of $2.84 \mathrm{~mm}$ per season at the sub-tropical range and $142.38 \mathrm{~mm}$ per season at temperate range but a decreasing trend of $71.58 \mathrm{~mm}$ per season at the upper tropical range. In the post-monsoon season, the average precipitation showed a decreasing trend of $23.89 \mathrm{~mm}$ per season at the upper tropical range, $6.71 \mathrm{~mm}$ per season in the sub-tropical range and $5.29 \mathrm{~mm}$ per season in the temperate range.

\subsubsection{Annual Precipitation Trend:}

As shown in Tables 7 and 8 , in the upper tropical range, the average annual precipitation is decreasing at the rate of $2.22 \mathrm{~mm}$ per year, 8.13 $\mathrm{mm}$ per the year in sub-tropical range and is increasing at the rate of $13.47 \mathrm{~mm}$ per year in temperate range. More moisture can be hold by a warmer atmosphere, and water vapor increases by $7 \%$ for every degree centigrade of warming globally [18]. Although, the translation of this phenonmenon to global changes in precipitation is quite unclear, the total volume of precipitation is likely to increase by $1-2 \%$ per degree of warming [18].

Table 7: Annual precipitation trend (2001-2008).

\begin{tabular}{clcccc}
\hline S. No. & Name of station & $\boldsymbol{\tau}$ & p-value & Sen's Slope & Trend \\
\hline \hline 1 & Pokhara Airport & -0.16 & 0.65 & -11.55 & Decreasing \\
2 & Malepatan & -0.02 & 0.58 & -12.30 & Decreasing \\
3 & Lumle & -0.14 & 0.51 & -12.53 & Decreasing \\
\hline \hline
\end{tabular}

Table 8: Annual precipitation trend (2001-2008)

\begin{tabular}{clcccc}
\hline S. No. & Name of station & $\boldsymbol{\tau}$ & p-value & Sen's Slope & Trend \\
\hline \hline 1 & Pokhara Airport & 0.05 & 0.53 & -0.33 & Decreasing \\
2 & Malepatan & 0.13 & 0.42 & 9.20 & Increasing \\
3 & Begnas & -0.05 & 0.55 & 0.82 & Increasing \\
4 & Lumle & 0.00 & 0.57 & -3.73 & Decreasing \\
5 & Panchase & 0.10 & 0.49 & 13.47 & Increasing \\
\hline
\end{tabular}

\subsection{Maximum Temperature Trend:}

\subsubsection{Seasonal Maximum Temperature Trend:}

Seasonal maximum temperature trend analysis was performed for the two periods which are shown in Table 9 and Table 10. In the winter season, maximum seasonal temperature showed an increasing trend of $0.17{ }^{\circ} \mathrm{C}$ per season in the upper tropical range and $0.06{ }^{\circ} \mathrm{C}$ per season in temperate- range but the decreasing trend of 0.05 ${ }^{\circ} \mathrm{C}$ per season in sub-tropical range. Similarly, in the pre-monsoon season, the maximum temperature decreases at the rate of $0.09{ }^{\circ} \mathrm{C}$ per season in the upper tropical range, $0.19^{\circ} \mathrm{C}$ per season in the sub-tropical range and $0.27{ }^{\circ} \mathrm{C}$ per season in temperature range. In the monsoon season, the maximum temperature is increasing by $0.07{ }^{\circ} \mathrm{C}$ per season in the upper tropical range but decreasing at the rate of $0.19^{\circ} \mathrm{C}$ per season in sub-tropical range and $0.17{ }^{\circ} \mathrm{C}$ per season in temperate range. In the post-monsoon season, the average maximum temperature is increasing at the rate of $0.1{ }^{\circ} \mathrm{C}$ per season in the upper tropical range, decreasing at the rate of $0.02{ }^{\circ} \mathrm{C}$ per season in the sub-tropical range and increasing at the rate of $0.05{ }^{\circ} \mathrm{C}$ per season in the temperate range. 
Table 9: Seasonal maximum temperature trend (1970-2009).

\begin{tabular}{|c|c|c|c|c|c|c|c|c|c|}
\hline $\begin{array}{l}\text { S. } \\
\text { No. }\end{array}$ & $\begin{array}{l}\text { Name of } \\
\text { Stations }\end{array}$ & $\tau$ & $\begin{array}{c}\text { p- } \\
\text { value }\end{array}$ & $\begin{array}{l}\text { Sen's } \\
\text { Slope }\end{array}$ & Trend & $\tau$ & $\begin{array}{c}\text { p- } \\
\text { value }\end{array}$ & $\begin{array}{l}\text { Sen's } \\
\text { Slope }\end{array}$ & Trend \\
\hline & & \multicolumn{4}{|c|}{ Winter } & \multicolumn{4}{|c|}{ Pre- Monsoon Season } \\
\hline 1 & $\begin{array}{l}\text { Pokhara } \\
\text { Airport }\end{array}$ & 0.03 & 1.00 & 0.01 & Increasing & 0.11 & 0.75 & 0.05 & Increasing \\
\hline 2 & Malepatan & 0.21 & 0.06 & 0.02 & Increasing & -0.20 & 0.08 & -0.04 & Decreasing \\
\hline \multirow[t]{2}{*}{3} & Lumle & 0.49 & 0.00 & 0.06 & Increasing & -0.10 & 0.40 & -0.03 & Decreasing \\
\hline & & \multicolumn{4}{|c|}{ Monsoon Season } & \multicolumn{4}{|c|}{ Post Monsoon Season } \\
\hline 1 & $\begin{array}{l}\text { Pokhara } \\
\text { Airport }\end{array}$ & 0.17 & 0.60 & 0.03 & Increasing & -0.22 & 0.47 & -0.06 & Decreasing \\
\hline 2 & Malepatan & -0.17 & 0.13 & -0.04 & Decreasing & 0.37 & 0.00 & 0.06 & Increasing \\
\hline 3 & Lumle & -0.04 & 0.71 & -0.01 & Decreasing & 0.54 & 0.00 & 0.09 & Increasing \\
\hline
\end{tabular}

Table 10: Seasonal maximum temperature trend (2010-2017).

\begin{tabular}{|c|c|c|c|c|c|c|c|c|c|}
\hline S. No. & $\begin{array}{l}\text { Name of } \\
\text { Stations }\end{array}$ & $\tau$ & $\begin{array}{c}\text { p- } \\
\text { value }\end{array}$ & $\begin{array}{l}\text { Sen's } \\
\text { Slope } \\
\end{array}$ & Trend & $\tau$ & $\begin{array}{c}\text { p- } \\
\text { value }\end{array}$ & $\begin{array}{l}\text { Sen's } \\
\text { Slope } \\
\end{array}$ & Trend \\
\hline & & \multicolumn{4}{|c|}{ Winter } & \multicolumn{4}{|c|}{ Pre- Monsoon Season } \\
\hline 1 & $\begin{array}{l}\text { Pokhara } \\
\text { Airport }\end{array}$ & 0.50 & 0.11 & 0.20 & Increasing & -0.36 & 0.27 & -0.19 & Decreasing \\
\hline 2 & Malepatan & 0.50 & 0.11 & 0.15 & Increasing & -0.21 & 0.54 & -0.19 & Decreasing \\
\hline 3 & Begnas & 0.86 & 0.00 & 0.33 & Increasing & -0.29 & 0.39 & -0.10 & Decreasing \\
\hline 4 & Lumle & -0.14 & 0.71 & -0.16 & Decreasing & -0.64 & 0.04 & -0.35 & Decreasing \\
\hline \multirow[t]{2}{*}{5} & Panchase & 0.21 & 0.54 & 0.06 & Increasing & -0.43 & 0.17 & -0.27 & Decreasing \\
\hline & & \multicolumn{4}{|c|}{ Monsoon Season } & \multicolumn{4}{|c|}{ Post Monsoon Season } \\
\hline 1 & $\begin{array}{l}\text { Pokhara } \\
\text { Airport }\end{array}$ & 0.64 & 0.03 & 0.12 & Increasing & 0.43 & 0.17 & 0.11 & Increasing \\
\hline 2 & Malepatan & 0.86 & 0.00 & 0.14 & Increasing & 0.43 & 0.17 & 0.11 & Increasing \\
\hline 3 & Begnas & 0.71 & 0.02 & 0.25 & Increasing & 0.57 & 0.06 & 0.19 & Increasing \\
\hline 4 & Lumle & -0.33 & 0.32 & -0.12 & Decreasing & -0.43 & 0.17 & -0.13 & Decreasing \\
\hline 5 & Panchase & -0.07 & 0.90 & -0.13 & Decreasing & 0.14 & 0.71 & 0.05 & Increasing \\
\hline
\end{tabular}

\subsubsection{Annual Maximum Temperature Trend:}

As Table 11 and Table 12 represent, the average annual maximum temperature is increasing at the rate of $0.082{ }^{\circ} \mathrm{C}$ per year in the upper tropical range. In the sub-tropical range, the average annual maximum temperature is decreasing at the rate of $0.06{ }^{\circ} \mathrm{C}$ per year. In the temperate range, the average annual maximum temperature is decreasing at the rate of $0.066^{\circ} \mathrm{C}$ per year.

Table 11: Annual maximum temperature trend (1970-2009).

\begin{tabular}{clcccc}
\hline S. No. & \multicolumn{1}{c}{ Name of station } & $\boldsymbol{\tau}$ & p-value & Sen's Slope & Trend \\
\hline \hline 1 & Pokhara Airport & 0.38 & 0.07 & 0.04 & Increasing \\
2 & Malepatan & 0.23 & 0.25 & 0.03 & Increasing \\
3 & Lumle & 0.37 & 0.01 & 0.05 & Increasing \\
\hline \hline
\end{tabular}


Table 12: Annual maximum temperature trend (2010-2017).

\begin{tabular}{clcccc}
\hline S. No. & Name of station & $\boldsymbol{\tau}$ & p-value & Sen's Slope & Trend \\
\hline \hline 1 & Pokhara Airport & 0.17 & 0.39 & 0.08 & Increasing \\
2 & Malepatan & 0.23 & 0.25 & 0.03 & Increasing \\
3 & Begnas & 0.32 & 0.29 & 0.16 & Increasing \\
4 & Lumle & -0.31 & 0.43 & -0.17 & Decreasing \\
5 & Panchase & -0.05 & 0.64 & -0.07 & Decreasing \\
\hline \hline
\end{tabular}

\subsection{Minimum Temperature Trend:}

\subsubsection{Seasonal Minimum Temperature Trend:}

Seasonal minimum temperature trend analysis was performed for the two periods, which are shown in Tables 13 and 14. In the winter season, the seasonal minimum temperature is increasing at the rate of $0.17^{\circ} \mathrm{C}$ per season in upper tropical range, it is increasing at the rate of $0.13{ }^{\circ} \mathrm{C}$ per season in the temperate region, and it is increasing at the rate of $0.34{ }^{\circ} \mathrm{C}$ per season in the sub-tropical region. Similarly, in the premonsoon season, the minimum temperature is increasing at the rate of $0.07{ }^{\circ} \mathrm{C}$ per season in the upper tropical range, $0.12{ }^{\circ} \mathrm{C}$ per season in the tropical range and decreasing at the rate of $0.1{ }^{\circ} \mathrm{C}$ per season in the temperate range. In the monsoon season, the maximum temperature is increasing at the rate of $0.04{ }^{\circ} \mathrm{C}$ per season in the upper tropical range, increasing at the rate of $0.02{ }^{\circ} \mathrm{C}$ per season in the sub-tropical range and increasing at the rate of $0.17{ }^{\circ} \mathrm{C}$ per season in the temperate range. In the post-monsoon season, the average maximum temperature is increasing at the rate of $0.001{ }^{\circ} \mathrm{C}$ per season in the upper tropical range, increasing at the rate of $0.09{ }^{\circ} \mathrm{C}$ per season in the subtropical range and no change in the temperate range.

\subsubsection{Annual Minimum Temperature Trend:}

Tables 15 and 16 represent the annual minimum temperature trend. In the upper tropical range, the average annual minimum temperature is increasing at the rate of $0.08{ }^{\circ} \mathrm{C}$ per year. In the sub-tropical range, the average annual maximum temperature is increasing at the rate of $0.057^{\circ} \mathrm{C}$ per year and in the temperate range the average annual maximum temperature is increasing at the rate of $0.08{ }^{\circ} \mathrm{C}$ per year.

Table 13: Seasonal minimum temperature trend (1970-2009).

\begin{tabular}{|c|c|c|c|c|c|c|c|c|c|}
\hline $\begin{array}{c}\text { S. } \\
\text { No. }\end{array}$ & $\begin{array}{l}\text { Name of } \\
\text { Stations }\end{array}$ & $\tau$ & $\begin{array}{c}\text { p- } \\
\text { value }\end{array}$ & $\begin{array}{l}\text { Sen's } \\
\text { Slope }\end{array}$ & Trend & $\tau$ & $\begin{array}{c}\text { p- } \\
\text { value }\end{array}$ & $\begin{array}{l}\text { Sen's } \\
\text { Slope }\end{array}$ & Trend \\
\hline & & \multicolumn{4}{|c|}{ Winter } & \multicolumn{4}{|c|}{ Pre- Monsoon Season } \\
\hline 1 & $\begin{array}{l}\text { Pokhara } \\
\text { Airport }\end{array}$ & 0.03 & 1.00 & 0.01 & Increasing & 0.11 & 0.75 & 0.05 & Increasing \\
\hline 2 & Malepatan & 0.51 & 0.00 & 0.09 & Increasing & 0.50 & 0.00 & 0.07 & Increasing \\
\hline \multirow[t]{2}{*}{3} & Lumle & 0.95 & 0.00 & 0.33 & Increasing & -0.16 & 0.14 & -0.02 & Decreasing \\
\hline & & \multicolumn{4}{|c|}{ Monsoon } & \multicolumn{4}{|c|}{ Post Monsoon Season } \\
\hline 1 & $\begin{array}{l}\text { Pokhara } \\
\text { Airport }\end{array}$ & 0.17 & 0.60 & 0.03 & Increasing & -0.22 & 0.47 & -0.06 & Decreasing \\
\hline 2 & Malepatan & 0.46 & 0.00 & 0.00 & Increasing & 0.39 & 0.01 & 0.06 & Increasing \\
\hline 3 & Lumle & 0.22 & 0.05 & 0.02 & Increasing & 0.06 & 0.62 & 0.00 & Increasing \\
\hline
\end{tabular}

\subsection{Precipitation Data Analysis:}

The data obtained from the local rain gauge was compared with the data obtained from the rain gauge installed by DHM at Begnas (Latitude: $28.10^{\circ} \mathrm{N}$, Longitude: $84.20^{\circ} \mathrm{E}$, and Elevation:
695 amsl). The data of 90 days were collected from the local rain gauge station and compared (Table 17). Fig. 3 shows the variation in cumulative precipitation recorded by these two different stations. The total amount of 
Himalayan Journal of Applied Science and Engineering (HiJASE), Vol. 1, Issue 1, No. 11, 2020

precipitation collected in the local rain gauge was established by the Department of Hydrology was $2129.4 \mathrm{~mm}$ (June-August, 2018), and the amount

1963.4 mm (June-August, 2018).

of precipitation collected by the rain gauge

Table 14: Seasonal minimum temperature trend (2010-2017).

\begin{tabular}{|c|c|c|c|c|c|c|c|c|c|}
\hline $\begin{array}{l}\text { S. } \\
\text { No. }\end{array}$ & $\begin{array}{l}\text { Name of } \\
\text { Stations }\end{array}$ & $\tau$ & $\begin{array}{c}\text { p- } \\
\text { value }\end{array}$ & $\begin{array}{l}\text { Sen's } \\
\text { Slope } \\
\end{array}$ & Trend & $\tau$ & $\begin{array}{c}\text { p- } \\
\text { value }\end{array}$ & $\begin{array}{l}\text { Sen's } \\
\text { Slope } \\
\end{array}$ & Trend \\
\hline & & \multicolumn{4}{|c|}{ Winter } & \multicolumn{4}{|c|}{ Pre- Monsoon Season } \\
\hline 1 & $\begin{array}{l}\text { Pokhara } \\
\text { Airport }\end{array}$ & 0.64 & 0.04 & 0.28 & Increasing & 0.07 & 0.90 & 0.05 & Increasing \\
\hline 2 & Malepatan & 0.29 & 0.39 & 0.25 & Increasing & 0.07 & 0.90 & 0.08 & Increasing \\
\hline 3 & Begnas & 0.50 & 0.11 & 0.19 & Increasing & 0.14 & 0.71 & 0.10 & Increasing \\
\hline 4 & Lumle & 0.62 & 0.07 & 0.36 & Increasing & 0.33 & 0.37 & 0.25 & Increasing \\
\hline \multirow[t]{2}{*}{5} & Panchase & 0.29 & 0.39 & 0.13 & Increasing & -0.21 & 0.54 & -0.10 & Decreasing \\
\hline & & \multicolumn{4}{|c|}{ Monsoon Season } & \multicolumn{4}{|c|}{ Post Monsoon Season } \\
\hline 1 & $\begin{array}{l}\text { Pokhara } \\
\text { Airport }\end{array}$ & 0.47 & 0.14 & 0.08 & Increasing & 0.50 & 0.11 & 0.12 & Increasing \\
\hline 2 & Malepatan & 0.36 & 0.27 & 0.06 & Increasing & -0.26 & 0.45 & -0.05 & Decreasing \\
\hline 3 & Begnas & 0.14 & 0.71 & 0.03 & Increasing & -0.07 & 0.90 & -0.03 & Decreasing \\
\hline 4 & Lumle & 0.14 & 0.76 & 0.03 & Increasing & 0.68 & 0.05 & 0.18 & Increasing \\
\hline 5 & Panchase & 0.29 & 0.39 & 0.17 & Increasing & -0.04 & 1.00 & 0.00 & No trend \\
\hline
\end{tabular}

Table 15: Annual minimum temperature trend (1970-2009).

\begin{tabular}{clcccc}
\hline S. No. & Name of station & $\boldsymbol{\tau}$ & p-value & Sen's Slope & Trend \\
\hline 1 & Pokhara Airport & 0.10 & 0.67 & 0.02 & Increasing \\
2 & Malepatan & 0.31 & 0.13 & 0.06 & Increasing \\
3 & Lumle & 0.07 & 0.41 & 0.00 & Increasing \\
\hline \hline
\end{tabular}

Table 15: Annual minimum temperature trend (2010-2017).

\begin{tabular}{clcccc}
\hline S. No. & Name of station & $\boldsymbol{\tau}$ & p-value & Sen's Slope & Trend \\
\hline \hline 1 & Pokhara Airport & 0.30 & 0.38 & 0.13 & Increasing \\
2 & Malepatan & 0.20 & 0.57 & 0.11 & Increasing \\
3 & Begnas & 0.17 & 0.49 & 0.07 & Increasing \\
4 & Lumle & 0.18 & 0.57 & 0.12 & Increasing \\
5 & Panchase & 0.19 & 0.52 & 0.08 & Increasing \\
\hline \hline
\end{tabular}

Table 16: Comparision of established and DHM rain gauge stations.

\begin{tabular}{ccc}
\hline Month & $\begin{array}{c}\text { Cumulative } \\
\text { precipitation } \\
\text { at DHM rain } \\
\text { gauge station } \\
(\mathbf{m m})\end{array}$ & $\begin{array}{c}\text { Cumulative } \\
\text { precipitation } \\
\text { at local rain } \\
\text { gauge station } \\
\text { (mm) }\end{array}$ \\
\hline \hline June & 578.5 & 671.5 \\
July & 831.5 & 708.0 \\
August & 553.4 & 750.0 \\
Total & 1963.4 & 2129.4 \\
Precipitation & 1963 & \\
\hline \hline
\end{tabular}

As the stations were not located exactly at the same place, slightly different values of precipitations are observed in those stations though it was similar for the first few days. Therefore, the local rain gauge station's precipitations values obviously differ with the precipitation values of DHM station if one keeps recording for a more extended period than the three months of record period for this study. 


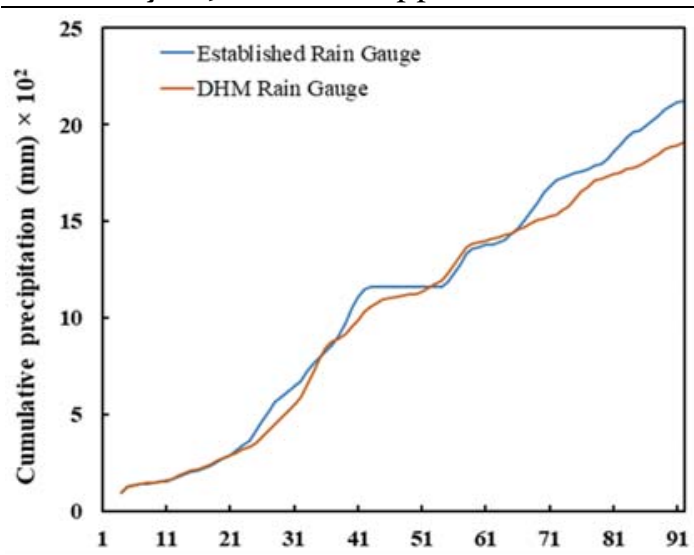

Figure 3: Comparison of cumulative precipitation ( $\mathrm{mm}$ ) of local and DHM rain gauge stations.

\section{Conclusion:}

The climate change study was performed for three climatic zones of Kaski, Nepal, namely; upper tropical region, sub-tropical region and temperate region. The main goal of this research was to analyze the climate changing trend by individual trend analysis of rainfall and temperature patterns by using the Mann-Kendell test. For the lower Kaski district, it is found that the seasonal precipitation in winter and pre-monsoon seasons are increasing, and the seasonal precipitation in monsoon and post-monsoon seasons are decreasing. The overall annual precipitation trend is decreasing. The seasonal maximum temperature trend of winter, monsoon and postmonsoon seasons are increasing and that of premonsoon season is decreasing. The overall annual maximum temperature trend is increasing. The seasonal minimum temperature trend of temperate region is decreasing whereas other two regions are increasing and the overall annual minimum temperature is also increasing. However this study is limited due to the use of insufficient data for trend analysis of climate change. Hence, it can be further extended in future to use climate data of more than thirty years. Furthermore detail assessment can be performed using the daily and monthly weather data as this study focused only on annual and seasonal trends.

In addition, a local rain gauge was established manually and compared to the rainfall data with a DHM station. Precipitation pattern from two methods was found similar but with the difference in numeric values of cumulative rainfall. It suggests that a locally established rain gauge station can help to obtain in-situ precipitation data for designing hydraulic structures. The World Meteorological Organization (WMO) suggests the minimum area for one rain gauge station to be less than $25 \mathrm{~km}^{2}$ for the mountainous region of the world's temperate and Mediterranean and tropical zone. But the station at Malepatan and Pokhara Airport is nearer and also the station at Lekhnath and Begnas are under the area of $25 \mathrm{~km}^{2}$, yet the precipitation varies spatially. Hence, in the districts like Kaski, where there is a heavy downpour and massive variation in precipitation patterns within such a short distance, the local rain gauge station readings need to be considered for economic hydrological constructions and to avoid the failures of hydraulic structures.

\section{References:}

[1] IPCC, "Climate change 2007: impacts, adaptation and vulnerability", Contribution of Working Group II to the Fourth Assessment Report of the Intergovernmental Panel on Climate Change, Cambridge University Press, Cambridge, UK, 2007.

[2] A. B. Shrestha, C. P. Wake, P. A. Mayewski, and J. E. Dibb, "Maximum temperature trends in the Himalaya and its vicinity: an analysis based on temperature records from Nepal for the period 1971-94", Journal of Climate, vol. 12, pp. 2775-2786, 1999.

[3] S. Addisu, Y. G. Sealassie, G. Fissha, and B. Gedif, "Time series trend analysis of temperature and rainfall in lake Tana sub-basin, Ethiopia", Environmental System Research, DOI: 10.1186/s40068015-0051-0, 2015.

[4] M. L. Shrestha, "Interannual variation of summer monsoon rainfall over Nepal and its relation to southern oscillation index", Meteorology and Atmospheric Physics, vol. 75, pp. 21-28, 2000.

[5] A. Dixit., " Climate Change in Nepal: Impacts and Adaptive Strategies"., Institution for Social and Environmental Transition-Nepal, World Resources Report., https://www.wri.org/our- 
work/project/world-resources-

report/climate-change-nepal-impacts-

and-adaptive-strategies.

[6] Government of Nepal, Ministry of Population and Environment, Department of Hydrology and Meteorology, "Observed climate trend analysis of Nepal (1971-2014)", 2017.

[7] K. Basnet and D. Acharya, "Flood analysis at Ramghat, Pokhara, Nepal using HEC-RAS", Technical Journal, vol. 1, no. 1, pp. 41-53, 2019. https://doi.org/10.3126/tj.v1i1.27591.

[8] S. Khadka and K. Basnet, "Storm water management of Barahi Chowk area, Lakeside, Pokhara, Nepal using SWMM", Proceedings of 2nd International Conference on Engineering \& Technology, Lalitpur, Nepal, vol. 2, pp. 320-325, 2019.

[9] K. Basnet and M. Neupane, "Storm water drainage design based on hydrological analysis: a case study on Lamachaur catchment area, Pokhara, Nepal", Oodbodhan: A Journal of TUTA, vol. 5, no. 1, pp. 100-109, 2018.

[10] A. Basarir, H. Arman, S. Hussein, A. Murad, A. Aldahan, M. A. Al-Abri, "Trend detection in annual temperature and precipitation using Mann-Kendall test - a case study to assess climate change in Abu Dhabi, United Arab Emirates", Proceedings of 3rd International Sustainable Buildings Symposium, Lecture Notes in Civil Engineering, vol. 7. Springer, Cham, 2017.

[11] S. S. Chinchorkar, D. M. Bhavin Ram, Paradava, and M. M. Trivedi, "A case study of temperature and rainfall trends using Mann-Kendall test in Saurashtra Region (Junagadh) of Gujaart, India",
International Journal of Environmental Sciences, vol. 6, no. 6, pp. 954-969, 2016.

[12] R. Ilaboya, "Non-parametric MannKendall test statistics for rainfall trend analysis in some selected states within the coastal region of Nigeria", Journal of Civil, Construction and Environmental Engineering, vol. 3, pp. 17-28, 2018.

[13] H. Motiee, E. McBean., "An Assessment of Long Term Trends in Hydrologic Components and Implications for Water Levels in Lake Superior “, Hydrology Research, 40.6, 564-579, 2009.

[14] K. Drapela, I. Drapelova., "Application of Mann-Kendall test and the Sen's slope estimates for trend detection in deposition data from Bílý Kř́ž (Beskydy Mts., the Czech Republic) 1997-2010", Beskdy Mendel University in Brno 4 (2), 133-146, 2011.

[15] P. Llukan., "Kendall's Tau". International Encyclopedia of Statistical Science., DOI: https://doi.org/10.1007/978-3-64204898-2_324, 2014.

[16] K. H. Hamed and A. Rao, "A modified Mann-Kendall trend test for autocorrelated data", Journal of Hydrology, vol. 204, pp.182-196, 1998.

[17] T. Sinha, K. Cherkauer, "Time series analysis of soil freeze and thaw processes in Indiana", Journal of Hydrometrology, https://doi.org/10.1175/2008JHM934.1, 2008.

[18] Will Climate Change Lead To More Rainfall And Extreme Floods In India?, Scientific India, https://scind.org/1294/Environment/will -climate-change-lead-to-more-rainfalland-extreme-floods-in-india.html , 2018. 